\title{
What makes you a 'hero' for nature? Socio- psychological profiling of leaders committed to nature and biodiversity protection across seven EU countries
}

Massimiliano Scopelliti, Erica Molinario, Flavia Bonaiuto, Mirilia Bonnes, Lavinia Cicero, Stefano De Dominicis, Ferdinando Fornara, Jeroen Admiraal, Almut Beringer, Tom Dedeurwaerdere, Wouter de Groot, Juha Hiedanpää, Paul Knights, Luuk Knippenberg, Katarina Polajnar Horvat, Florin Popa, Carmen Porras-Gomez, Aleš Smrekar, Nathalie Soethe, Jose Luis Vivero-Pol, Riyan van den Born \& Marino Bonaiuto

To cite this article: Massimiliano Scopelliti, Erica Molinario, Flavia Bonaiuto, Mirilia Bonnes, Lavinia Cicero, Stefano De Dominicis, Ferdinando Fornara, Jeroen Admiraal, Almut Beringer, Tom Dedeurwaerdere, Wouter de Groot, Juha Hiedanpää, Paul Knights, Luuk Knippenberg, Katarina Polajnar Horvat, Florin Popa, Carmen Porras-Gomez, Aleš Smrekar, Nathalie Soethe, Jose Luis Vivero-Pol, Riyan van den Born \& Marino Bonaiuto (2018): What makes you a 'hero' for nature? Socio-psychological profiling of leaders committed to nature and biodiversity protection across seven EU countries, Journal of Environmental Planning and Management, DOI: 10.1080/09640568.2017.1421526

To link to this article: https://doi.org/10.1080/09640568.2017.1421526

View supplementary material $\asymp$

Submit your article to this journal
Published online: 16 Feb 2018.

View Crossmark data \ulcorner 


\title{
What makes you a 'hero' for nature? Socio-psychological profiling of leaders committed to nature and biodiversity protection across seven EU countries
}

\author{
Massimiliano Scopelliti ${ }^{\mathrm{a}, \mathrm{b} *}$, Erica Molinario ${ }^{\mathrm{b}, \mathrm{c}}$, Flavia Bonaiuto $^{\mathrm{e}}$, Mirilia Bonnes (] ${ }^{\mathrm{b}}$, \\ ${\text { Lavinia } \text { Cicero }^{\mathrm{c}} \text {, Stefano De Dominicis } \text { (b) }^{\mathrm{b}, \mathrm{c}} \text {, Ferdinando Fornara }}^{\mathrm{c}, \mathrm{d}}$, Jeroen Admiraal ${ }^{\mathrm{f}}$, \\ Almut Beringer $^{\mathrm{g}}$, Tom Dedeurwaerdere ${ }^{\mathrm{h}}$, Wouter de Groot ${ }^{\mathrm{f}, \mathrm{i}}$, Juha Hiedanpää ${ }^{\mathrm{j}}$, \\ Paul Knights ${ }^{\mathrm{k}}$, Luuk Knippenberg ${ }^{\mathrm{i}}$, Katarina Polajnar Horvat ${ }^{1}$, Florin Popa ${ }^{\mathrm{m}}$, \\ Carmen Porras-Gomez ${ }^{\mathrm{h}}$, Aleš Smrekar ${ }^{1}$, Nathalie Soethe ${ }^{\mathrm{g}}$, Jose Luis Vivero-Pol ${ }^{\mathrm{h}}$, \\ Riyan van den Born ${ }^{\mathrm{i}}$ and Marino Bonaiuto (1) ${ }^{\mathrm{b}, \mathrm{c}}$
}

${ }^{a}$ Dipartimento Di Scienze Umane, Libera Università Maria Ss. Assunta (LUMSA), Rome, Italy; ${ }^{b}$ CIRPA - Centro Interuniversitario Di Ricerca in Psicologia Ambientale, Rome, Italy; ${ }^{c}$ Dipartimento Di Psicologia dei Processi di Sviluppo e Socializzazione, Sapienza Università Di Roma, Rome, Italy; ${ }^{d}$ Dipartimento Di Pedagogia, Psicologia, Filosofia, Università degli Studi di Cagliari, Cagliari, Italy; ${ }^{e}$ Dipartimento Di Medicina sperimentale, Sapienza Università Di Roma, Rome, Italy; ${ }^{f}$ Institute of Environmental Sciences, Leiden University, Leiden, The Netherlands; ${ }^{g}$ Institut Für Botanik und Landschaftsökologie, Ernst-Moritz- Arndt Universität, Greifswald, Germany; ${ }^{h}$ Biodiversity Governance Unit (BIOGOV), Centre for Philosophy of Law, Université catholique De Louvain, Louvain-La-Neuve, Belgium; ${ }^{i}$ Institute for Science, Innovation and Society, Faculty of Science, Radboud University, Nijmegen, The Netherlands; ${ }^{j}$ Natural Resources Institute Finland (Luke), Turku, Finland; ${ }^{k}$ School of Social Sciences, University of Manchester, Manchester, UK; ${ }^{l}$ Research Center of Slovenian Academy of Science and Arts, Anton Melik Geographical Institute, Ljubljana, Slovenia; ${ }^{m}$ European Commission, DG Education and Culture, Brussels, Belgium

(Received 14 December 2016; final version received 20 December 2017)

\begin{abstract}
Biodiversity loss is a widely debated world problem, with huge economic, social, and environmentally negative consequences. Despite the relevance of this issue, the psychological determinants of committed action towards nature and biodiversity have rarely been investigated. This study aims at identifying a comprehensive socialpsychological profile of activists committed to biodiversity protection and at understanding what determinants best predict their activism. A questionnaire investigating relevant social-psychological constructs identified in the literature on environmental activism was administered to 183 outstanding leaders (vs. non-leaders) in biodiversity protection across seven EU countries. Leaders (vs. non-leaders) in biodiversity protection showed, among other constructs, higher scores on environmental values, attitudes, identity, perceived control, a feeling of union and spirituality with nature, and willingness to sacrifice for their cause. Results are discussed within the theoretical framework of a motivation model of committed action for nature and biodiversity protection. Applications of the results are also proposed.
\end{abstract}

Keywords: nature; biodiversity; motivation; activism; social psychology

\section{Introduction}

Humanity is overloading the life-support systems of the biosphere because of several interrelated negative trends: population growth, increases in natural resource

*Corresponding author. Email: m.scopelliti@lumsa.it 
consumption, pollution, and biodiversity loss (Amel et al. 2017). The consequent environmental crisis can be solved only with the full responsibility of the whole society, through commitment at the individual, organizational, and collective level. Scholars claim the necessity of taking pro-environmental actions on several fronts, including the protection of natural areas and biodiversity (Clayton et al. 2015; Steg and Vlek 2009). Biodiversity is defined as the variety of life forms within and between ecosystems, which also provides humankind with the resources to live: food, energy, clean air and water, and, in general, ecosystem services. It plays a central ecological role for both the shorter term resilience of natural habitats and the long-term functioning of any terrestrial, marine or aquatic ecosystem (Millennium Ecosystem Assessment 2005). Despite this evidence, human-induced changes to ecosystems have increased over the past 50 years (Ceballos et al. 2015). Research has demonstrated that human activities have huge negative effects on nature and biodiversity (Foley et al. 2011; Halpern et al. 2008). Conversely, saving biodiversity has positive consequences not only from a bio-ecological perspective, but also in economic, social and cultural terms (Bonnes et al. 2011; Dudgeon et al. 2006; Gorenflo et al. 2012). Several studies have proposed conservative estimates of the economic benefits of saving global biodiversity, ranging from about $\$ 3,000$ to about $\$ 30,000$ billion per year, with a benefit:cost ratio of around 100:1 (Balmford et al. 2002; Costanza et al. 1997).

Recently, natural scientists and policy makers are jointly striving to halt the loss of biodiversity, the former identifying species at risk and direct causes of biodiversity loss (Maxwell et al. 2016), so that intervening for the latter becomes more possible than in the past. The European Commission adopted an integrative strategy to halt biodiversity loss within the EU by 2020, investing millions of Euros in innovative research projects. Such a challenge requires durable committed action, for which high levels of motivation are essential. In this regard, the role of outstanding environmental activists in the protection of biodiversity is fundamental (Amel et al. 2017).

\subsection{Who are environmental activists?}

The term 'environmental activists' identifies those people committed in environmentrelated behaviours (Dono, Webb, and Richardson 2010; James, Bixler, and Vadala 2010). Within social and psychological literature environmental activists include people who are willing to perform difficult environmental behaviours (James, Bixler, and Vadala 2010; Séguin, Pelletier, and Hunsley 1998); involved in high scholar level work in naturerelated fields (James, Bixler, and Vadala 2010); members of environmental groups or organizations (Edwards and Oskamp 1992; Stern et al. 1999); and committed in collective actions to support the environmental movement (Brechin and Kempton 1994). The study of their social-psychological profile is thus essential to identify the key factors leading people - both as individuals and through collective action - towards environmental protection, and then to find strategies to address the general population towards more sustainable conduct.

In this work, a more comprehensive definition in line with Séguin, Pelletier, and Hunsley (1998) is embraced, claiming that "environmental activists are people who intentionally engage in the most difficult ecological behaviours" that require a certain level of commitment and energy to be acted, often through the "association to an environmental organisation" and "also try to influence people's attitudes and behaviours towards the environment" (630-631). 


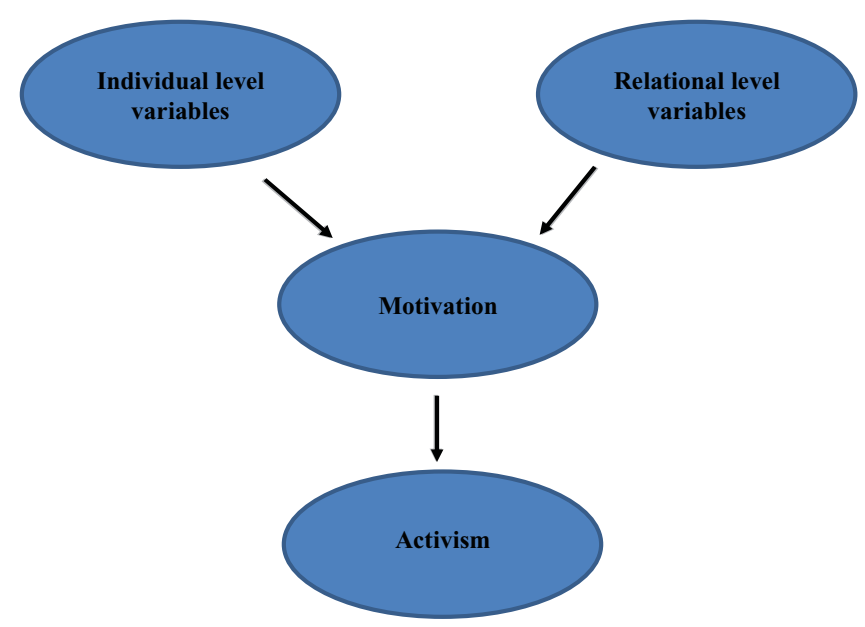

Figure 1. Integrative Model of Activism for nature and Biodiversity Protection (MABP).

\subsection{Social-psychological determinants of environmental activism}

Environmental activism represents such a peculiar behaviour that its determinants are likely to come from different levels of psychological analysis, ranging from individual to relational, the latter including both social and organizational determinants (Stern and Oskamp 1987). Far from being unrelated, those determinants can be considered within an integrative model that is proposed and tested in this study with reference to nature and biodiversity protection (Figure 1).

The idea that human action is the outcome of integration between individual and relational factors is well-established in psychological literature. The Theory of Reasoned Action (TRA; Fishbein and Ajzen 1975) and its extension, the Theory of Planned Behaviour (TPB; Ajzen 1991), which have been applied in predicting a variety of human behaviours (see Armitage and Conner 2001, for a review), share common assumptions with our framework. Basically, both TRA/TPB and our framework propose that people move to action (hence also environmental activism in general, and for nature and biodiversity protection in particular) when they develop a motivational force towards performing a given behaviour (intentions, in TRA/TPB), and this motivational force is influenced by both individual variables (attitudes, in TRA/TPB, and perceived behavioural control, in TPB only) and relational variables (subjective norms, in TRA/TPB). Attitudes are conceived as the evaluation of people, objects, or ideas; perceived behavioural control refers to the beliefs about the ease/difficulty of performing a given behaviour; and subjective norm refers to the beliefs about the approval/disapproval of that behaviour by significant others. Based on this framework, we proposed that several relevant variables influencing environmental activism could be referred to both the individual and the relational level, as well as to motivation. The role of these variables has been differently considered in the literature, and it is discussed in the following sections.

\subsubsection{The individual level: from values and worldviews to attitudes and personal obligation}

From a psychological perspective, the individual level of analysis has undoubtedly been the most deeply investigated, and several variables have been identified as being associated with pro-environmental behaviour and activism. Among general 
psychological constructs, Schwartz (1992) identified universal human values as guiding principles of everyday action. The author proposed the existence of 56 values, which can be clustered in four value orientations: self-transcendence (e.g. universalism), selfenhancement (e.g. power), openness to change (e.g. stimulation), and conservatism (e.g. security). In particular, self-transcendence and self-enhancement can affect environmental worldviews, which in turn influence concern for the environment and proenvironmental behaviour (Schultz et al. 2005). With reference to worldviews, Dunlap and Van Liere (1978) have claimed that a shift from anthropocentrism towards a New Environmental Paradigm (NEP) has occurred during the ' 70 s in Western societies. NEP is an ecocentric worldview stressing the importance of posing limits to growth, preserving the balance of nature, and rejecting the idea that nature exists solely for human use.

The influence of values and worldviews on pro-environmental behaviour has often been conceptualized within hierarchical frameworks, moving from general to more specific psychological constructs, such as attitudes (McFarlane and Boxall 2003; Vaske and Donnelly 1999). Corral-Verdugo et al. (2009) have recently found empirical support to the role of Affinity Towards Diversity (ATD), an attitude that refers to the appreciation of the dynamic variety of human-nature interactions, in predicting pro-environmental behaviour. In general, the role of attitudes in predicting individual and collective proenvironmental behaviour has been consistently found within TRA and TPB (see Steg and Vlek 2009, for a review).

More comprehensively, a hierarchical causal path has been proposed in the Value-Belief-Norm Theory (VBN, Stern et al. 1999). In order to explain public support for environmental movements, the authors showed that people engage in proenvironmental behaviours because general values such as self-transcendence and selfenhancement influence ecocentric worldviews (NEP, in their original theory); these, in turn, affect more specific beliefs about the negative consequences of bad environmental conditions. The awareness of environmental threat can lead people to ascribe to themselves the responsibility for action and, finally, activates a sense of moral normative obligation leading to behaviour.

\subsubsection{The relational level: social identity, human-nature connection and organizational membership}

Within the psychological literature, the relational level of analysis of pro-environmental behaviour and activism has been less extensively addressed than the individual one. Nonetheless, relevant variables have been identified. Social Identity Theory (SIT) gives a solid framework for this approach (Brown 2000). SIT considers achieving high levels of self-esteem as a basic human motivation. Nevertheless, humans are also naturally inclined to be group members to satisfy affiliation and protection needs. Part of their identity is thus dependent on the social groups to which they belong, and personal selfesteem is intrinsically related to the group's positive distinctiveness. A strong identification with a group thus leads the individual to promote a positive group image through maintaining a positive self-image (Hewstone, Rubin, and Willis 2002). This process can also lead to activism (Simon et al. 1998; van Zomeren, Postmes, and Spears 2008). Similarly, if SIT is transposed to the place level, when people strongly identify with a place, their personal identity can be positively maintained through the conservation of positive environmental qualities of that place (Bonaiuto, Breakwell, and Cano 1996; Twigger-Ross, Bonaiuto, and Breakwell 2003). This makes it more likely for 
the person to show interest in that territory and to engage in pro-environmental behaviour and environmental activism (Bonaiuto et al. 2002; Bonaiuto et al. 2008; Dono, Webb, and Richardson 2010; Scannell and Gifford 2010). Sometimes, the process of identification can go beyond a specific place to embrace the natural world as a whole, as expressed in the constructs of 'environmental identity' (Clayton 2003) and 'Inclusion of Nature in the Self’ (INS; Schultz 2001).

Also some worldviews can be included in this relational framework. Traditionally, the relationship between anthropocentric and ecocentric worldviews emerged to be negative in empirical studies in Western cultures, thus suggesting mutual incompatibility (Casey and Scott 2006). Conversely, cross-cultural research often found a positive correlation between the two worldviews (Bechtel, Corral-Verdugo, and de Queiroz Pinheiro 1999; Bechtel et al. 2006). From these results, Corral-Verdugo et al. (2008) have more recently claimed that an integrative perspective can be identified in their New Human Interdependence Paradigm (NHIP). NHIP stresses the long-term interdependence between human development and nature conservation and between the well-being of current and future generations (Bonnes and Bonaiuto 2002). Research findings by CorralVerdugo et al. (2008) showed that NHIP can be a stronger predictor of pro-environmental behaviour than the old NEP. The same idea of human-nature interdependence has been investigated from a more emotional point of view, leading to the development of the construct of Connectedness to Nature (CNS) and its valid and reliable measure (Mayer and Frantz 2004). This emotional bond with nature was found to predict some proenvironmental behaviours, such as the protection of vegetation among farmers (Gosling and Williams 2010).

From a different disciplinary perspective, De Groot Drenthen and De Groot (2011) critically discuss the visions of human/nature relations shared among laypeople, and their mutual bonds. Going beyond the anthropocentric/ecocentric distinction, the authors claim that public environmental ethics can be framed within four main visions about Human and Nature relations, measured by the HaN scale, namely: mastery over nature, highlighting the higher value of humans and the right to mould nature to human needs; stewardship of nature, stressing the need for humans to take care for nature; partnership with nature, reflecting an equal value, and mutual support, of both; and participation in nature, expressing the feeling of inclusion of humans in nature.

The human/nature bonds represent a central issue in the relational level of analysis of environmental activism. However, environmental activism also strongly relies on the relations between the activist and a group/organization interested in environmental initiatives (Séguin, Pelletier, and Hunsley 1998). To give an example, self-efficacy (i.e., the perception of being able to succeed when pursuing a goal; Bandura 1982) has frequently emerged as a relevant determinant of pro-environmental behaviour and activism (Barr 2007). Nonetheless, some research findings showed that the perception of collective efficacy is more likely to lead to environmental action (Homburg and Stolberg 2006). In addition, managers in organizations feel more empowered when they perceive, among other factors, working in a participative unit climate (Spreitzer 1996). Another relevant aspect of organization efficacy has to do with the relationships between leaders and co-workers. The concept of transformational leadership, implying the leader's capability to empower his/her followers, so that they can perform their tasks more independently, cohesively, and effectively, has assumed a relevant role (Bass and Riggio 2006). Consistent empirical findings have indeed shown that transformational leadership is related to improved self- and collective-efficacy, group membership, and quality of performance (Pillai and Williams 2004; Walumbwa et al. 2004). 


\subsubsection{Towards an integrative framework of activism: the role of motivation}

Séguin, Pelletier, and Hunsley (1998) have stressed the importance of a strong motivation among activists. Motivation refers to the psychological process eliciting, controlling, and sustaining behaviours. A variety of theories of human motivations has been developed in psychological science ever since. Traditionally, the most basic distinction is between intrinsic motivation (i.e., doing something because it is inherently interesting or enjoyable), and extrinsic motivation (i.e., doing something because it leads to an instrumentally positive outcome) in Self-Determination Theory (SDT; Ryan and Deci 2000). The central focus of SDT is the process of internalization through which external regulations and values become integrated into the self.

Within this framework, different variables referring to motivation were shown to be relevant for this study. A recent model of motivation has been proposed and empirically tested explaining terrorism, as a case of extreme behaviour (Kruglanski and Orehek 2011). However, Kruglanski et al. (2013) stressed that this motivation, namely Quest for Personal Significance (QPS) can also be channelled into a positive path, leading therefore to constructive goals. Like any motivational force, QPS needs to be activated in order to affect behaviour. Significance loss, threat of loss, and opportunity for significance gain can awaken QPS. This activation invites a collectivistic shift, and this encourages individuals to sacrifice on the group's behalf in order to gain significance (Kruglanski and Orehek 2011). The crucial feature of QPS is to attain what the culture or the group says it is worth attaining. When ideologies are empathically positive and pro-social, individuals may be willing to sacrifice personal goals and perform unselfish behaviours. Experimental evidence indeed shows that when one's mortality is made salient, thus threatening personal significance, individuals primed with positive values are more willing to act prosocially (Rothschild, Abdollahi, and Pyszczynski 2009).

Finally, with reference to environmental issues, Schultz (2001) has investigated how different aspects of concern for the environment can represent a motivational drive for action. In his study, three main dimensions of concern were identified, namely biospheric, referring to the well-being of plants and animals; egoistic, referring to the negative consequences of environmental change for the self; and altruistic, referring to the impact of environmental problems on others, including future generations.

Our claim is that motivation is the key determinant of committed action and activism: it collects different individual and relational social-psychological antecedents and turns them into action. Several empirical works have been made to understand how some of these variables relate to one another, and how they lead to pro-environmental behaviour (Dietz, Stern, and Guagnano 1998; Klockner 2013). Nonetheless, a complete path did not undergo a thorough test. For example, in a study on activism in the forest sector, McFarlane and Hunt (2006) found an interaction effect of several social-psychological variables, including values, attitudes, and identity, with contextual factors referring to the economic and cultural context of respondents. Dedeurwaerdere et al. (2016) found empirical support for the role of the governance framework in promoting selfdetermination of the actors (such as feelings of autonomy of choice and competence) in key biodiversity initiatives. Also, the role of organizational network of activists was considered. For example, Fielding, McDonald, and Louis (2008) have integrated TPB with identity variables, and found that, beyond positive attitude, normative support, and a stronger sense of the self as an environmental activist, also a greater involvement in environmental groups increases intention to engage in environmental activism. Similarly, Dedeurwaerdere, Polard, and Melindi-Ghidi (2015) have shown that a greater involvement in nature protection organizations improves behavioural change in favour of 
biodiversity amongst farmers. Botetzagias and van Schuur (2012) have investigated activism in green political parties among 12 European countries, including identity and macro-level variables, and found that both membership in environmental organizations and contextual factors (such as the quality of the country's natural environment and environmental policies) significantly influenced activism.

Nonetheless, these examples are still scant: Ives (2016) reported that only about $2 \%$ of multidisciplinary studies about people and nature analysed activists. Moreover, the analysis of the relationships between the individual and relational determinants of activism is often fragmented, and the role of motivation not always accurately considered. In addition, which factors motivate activism in the case of biodiversity protection is still an unexplored issue, especially within a multivariate perspective considering together all the factors investigated by the literature. Finally, the literature on the social-psychological determinants of pro-environmental behaviour and activism has often proposed a correlational approach without any comparison with a contrast group.

\subsection{The study}

The first step towards a comprehensive Model of Activism for nature and Biodiversity Protection (MABP) has to do with the identification of the most relevant socialpsychological determinants at the different levels of analysis considered in the literature, and the key motivations leading to committed action. The second step is to identify their relative importance within an integrative framework.

According to MABP (Figure 1), the relevant constructs to identify nature and biodiversity activists can be organized as follows: (1) individual level (universal values, ATD, perceived behavioural control, awareness of consequences, ascription of responsibility, personal normative beliefs, and self-efficacy); (2) relational level (subjective norms, place identity, environmental identity, INS, NHIP, CNS, HaN, collective efficacy, organizational empowerment, and transformational leadership); (3) motivation (willingness to sacrifice, motives for environmental concern, and motives for action towards biodiversity protection); and (4) action (pro-environmental behaviours and activism).

Active leaders in the protection of nature and biodiversity sampled from seven European Countries taking part in the BIOMOT EC 7th FP (Belgium, Finland, Germany, Italy, Slovenia, The Netherlands, and UK) were involved in this study (De Groot et al. 2015). In order to warrant generalization of results, participants were also selected from three different sectors within each country, namely business (e.g. companies involved in tourism, fishing, and food production); civil society (e.g. non-governmental organizations, foundations, and civil activists); and public sector (e.g. local governments and UNESCOMAB networks). A selection process identifying leaders who initiated outstanding actions and received acknowledgements for biodiversity protection (people with High Motivation in Action towards Nature, HM-AN) was carried out. A comparison group of participants was also considered, including (1) leaders in society-related activities not referring to nature and biodiversity; and (2) collaborators of HM-AN leaders, not recognized for their outstanding action. Participants in the latter two categories were labelled as "Not Outstanding in Action towards Nature (NO-AN)." Both groups of participants were administered a questionnaire investigating the above constructs.

\section{Aims and hypotheses}

The aim of the study was to outline a comprehensive social-psychological profile of HM$\mathrm{AN}$, testing the differences between HM-AN and NO-AN in terms of (1) individual 
psychological variables; (2) relational variables; (3) motivation; (4) behaviours associated with nature and biodiversity protection; and finally, (5) to test the integrative MABP.

Preliminarily, the psychometric features of the adopted tools and the validity of the contrasted samples for the higher vs. lower degree of action towards nature and biodiversity protection were checked. Then the following hypotheses were tested:

H1: HM-AN leaders (vs. NO-AN) are expected to score higher on nature-related universal values, ATD, perceived behavioural control, awareness of consequences, ascription of responsibility, personal normative beliefs, and self-efficacy;

H2: HM-AN leaders (vs. NO-AN) are expected to score higher on subjective norms, place identity, environmental identity, INS, NHIP, CNS, and HaN than NO-AN leaders; with reference to collective efficacy, organizational empowerment, and transformational leadership, the literature does not suggest specific hypotheses;

H3: HM-AN leaders (vs. NO-AN) are expected to score higher on willingness to sacrifice, motives for environmental concern, and motives for action towards the protection of biodiversity;

H4: HM-AN leaders (vs. NO-AN) are expected to score higher on pro-environmental behaviours and activism;

$\mathrm{H} 5$ : predictors from both the individual and the relational level of analysis are expected to influence motivation towards nature and biodiversity protection, and this, in turn, to affect activism.

\section{Method}

\subsection{Participants and procedure}

A total of 350 people were first e-mailed and asked to participate in the BIOMOT project by filling in a web survey; 183 participants from the seven BIOMOT partners agreed (130 men, 49 women, and 4 missing information; $M_{\text {age }}=50.55, \mathrm{SD}_{\mathrm{age}}=11.33$; Belgium $=$ $19.12 \%$; Finland $=9.84 \%$; Germany $=18.03 \%$; Italy $=13.66 \%$; Slovenia $=16.39 \%$; The Netherlands $=11.48 \%$; and UK $=11.48 \%)$. Participants were HM-AN $(N=68)$ and NOAN $(N=115)$. NO-AN were leaders in society-related activities $(N=69)$ and HM-AN's collaborators $(N=46)$.

Validated scales in the country language were adopted when available. Otherwise, the scale items have been translated into the languages of the BIOMOT partners following the back-translation procedure. Data were gathered in 2013-2014. The questionnaire has been administered via the UNIPARK online software.

\subsection{Measures}

Given the high number of constructs considered, most of them have been measured through a two-item scale, in order to avoid cognitive loading on the respondents. With the exception of the "Motives for action towards the protection of biodiversity" tool (BIOMOT-20 Motives scale, B20), which was ad hoc created, items were selected from validated scales, based on conceptual (i.e., item content referring to the measured construct) and statistical (i.e., high factor loading on the reference factor) reasons. Details on the scales are given below. A final section on socio-demographics was included. 


\subsubsection{Individual level variables}

Universal values: 29 items by Schwartz (1992, e.g. 'unity with nature', 'protecting the environment', 'social justice', 'creativity', 'social power', and 'pleasure'). Participants were asked to rate how much each value was an important guiding principle in their life on a scale ranging from 1 (strongly unimportant) to 7 (strongly important).

ATD: two items by Corral-Verdugo et al. (2009, "I like many kinds (species) of animals, not only a few of them" and "For me the greater the variety of plants species, the better").

Perceived behavioural control: two adapted items by Fornara et al. (2011, "For me acting to protect nature and biodiversity is easy" and "For me acting to protect nature and biodiversity is feasible").

Awareness of consequences: two adapted items by Stern et al. (1999, "Nature and biodiversity will provide a better world for me and my children" and "Nature and biodiversity damage generated here harms people all over the world").

Ascription of responsibility: two adapted items by Schultz et al. (2005, "I feel personally responsible for the protection of nature and biodiversity" and "My role in the protection of nature and biodiversity is small").

Personal normative beliefs: two adapted items by Stern et al. (1999, "I feel personally obliged to protect nature and biodiversity" and "I feel guilty when I do not act for nature and biodiversity protection").

Self-efficacy: two items by Chen, Gully, and Eden (2001, e.g. "I will be able to successfully overcome many challenges" and "Compared to other people, I can do most tasks very well").

With the exception of universal values, responses for each variable were collected on a scale ranging from 1 (strongly disagree) to 7 (strongly agree).

\subsubsection{Relational level variables}

Subjective norms: two adapted items by Fornara et al. (2011, "Most people who are important to me think that I should act for nature and biodiversity" and "Most of the people who are important to me do act to protect nature and biodiversity").

Place identity: four adapted items by Vaske and Kobrin (2001). A place was previously identified as the target of the respondent's environmental action. The choice was between 'world', 'country', 'county/region', 'city', 'neighbourhood', and 'other'. Example items are "I feel X is a part of me" and "No other place can compare to X".

Environmental identity: two adapted items from Clayton (2003, "I would feel that an important part of my life was missing if I was not able to get out and enjoy nature and biodiversity from time to time" and "I feel that I receive spiritual sustenance from nature and biodiversity").

INS: a single item by Schultz (2001) has been included. Participants were asked to select, from a series of seven overlapping circles labelled 'self' and 'nature', the pair that best represented their sense of connection to the natural world. Scores ranged from 1 (the circles were completely separated) to 7 (the circles were completely overlapping). 
NHIP: two items by Corral-Verdugo et al. (2008, "Human beings can progress only by conserving nature's resources" and "Human progress can be achieved only by maintaining ecological balance").

CNS: two items from Mayer and Frantz (2004, "I often feel a sense of oneness with the natural world around me" and "My personal welfare is independent of the welfare of the natural world").

$H a N$ : eight items from De Groot Drenthen and De Groot (2011), referring to mastery over nature (e.g. "Human beings have more value than nature"); stewardship of nature (e.g. "Human beings have a responsibility to conserve the natural environment"); partnership with nature (e.g. "People and nature are of equal value"); and participation in nature (e.g. "When I am surrounded by nature I experience something greater than mankind").

Collective efficacy: two adapted items from Walumbwa et al. (2004, "My work group can find solutions to problems with its performance" and "I believe that failure will make our work group try harder").

Organizational empowerment: two items by Spreitzer (1996, "I have significant autonomy in determining how I do my job" and "My impact on what happens in my organization/association is large").

Transformational leadership: two adapted items by Bass and Riggio (2006, "The leader of my organization expresses confidence that goals will be achieved" and "The leader of my organization talks optimistically about the future").

With the exception of the INS scale, responses for each variable were collected on a scale ranging from 1 (strongly disagree) to 7 (strongly agree).

\subsubsection{Motivation}

Willingness to sacrifice: two adapted items by Stern et al. (1999, "I would be willing to accept a change in my standard of living to protect nature and biodiversity" and "I would be willing to pay higher prices to buy goods, if this would help to protect nature and biodiversity").

Motives for environmental concern: 12 items by Schultz (2001), referring to 'marine life', 'birds', 'animals', and 'plants' (biospheric motive); 'my health', 'my future', 'my lifestyle', and 'me' (egoistic motive); and 'my country', 'children', 'all people', and 'my children' (altruistic motive).

With reference to both variables, participants were asked to rate their agreement on a scale ranging from 1 (strongly disagree) to 7 (strongly agree).

B20: the B20 scale (Admiraal et al. 2017) has been developed through the analysis of multidisciplinary literature and backgrounds of BIOMOT researchers. The items tap 20 different motives to act for nature and biodiversity protection (e.g. 'personal benefit', 'pleasure in collaborating with others', 'value of nature in itself', 'desire to live a worthy life', 'negative emotions towards the others', 'desire to gain recognition', and 'connectedness to something larger than myself'). Participants were asked to rate the importance of each motive on a scale ranging from 1 (strongly unimportant) to 7 (strongly important). 


\subsubsection{Concrete actions level}

Disposition to connect to nature: eight items by Mayer and Frantz (2004, e.g. "I cross meadows barefoot", "I talk to plants", and "I help animals (e.g. snails) cross the street").

Pro-environmental behaviours: four items from the General Ecological Behaviour (GEB) scale by Kaiser (1998), referring to recycling (i.e., "I collect and recycle used paper" and "I bring empty bottles to a recycling bin") and transportation choice behaviours (i.e., "I bring empty bottles to a recycling bin" and "When possible in nearby areas I use public transport or ride a bike"); two adapted items by Dutcher et al. (2007), referring to selfeducation (e.g. "I attended a public hearing or meeting about the environment" and "I changed my behaviour in any way because of concern for the environment"); six items from Bélanger (2012), referring to difficult non-normative (hard) and normative (soft) behaviours (e.g. "I joined a radical activist group to perform risky or illegal actions in order to help the environmental cause" and "I sensitised close relatives or colleagues in order that they change their habits and undertake eco-friendly behaviours").

Participants were asked to rate the frequency of each behaviour on a scale ranging from 1 (never) to 7 (always).

Activism: five ad hoc items (i.e., "I am very active in the protection of nature/ biodiversity", "My activities to protect the plant world involve many different species", "My activities to protect the animal world involve many different species", "My activities to protect nature/biodiversity involve rare (or endangered) species" and "In my free time I spend a lot of time in groups/clubs dealing with nature"). Participants were asked to rate their agreement with those statements using a scale ranging from 1 (strongly disagree) to 7 (strongly agree).

\section{Data analyses and results}

\subsection{Factor and reliability analyses}

A principal component Exploratory Factor Analysis (EFA) was performed on the B20 scale with Oblimin rotation. Both scree-plot and factor loadings suggested a three-factor solution, supported by both conceptual and statistical reasons (Table 1). The three dimensions were labelled: (1) "Positive self and relations with others and nature", referring to a feeling of connection between self, other people, and the world in general; (2) "Power of self and negative emotions towards the others", referring to feelings of power and negative drives for nature and biodiversity protection; and (3) "Union and spirituality", referring to the idea of connectedness with nature and spiritual drives for nature and biodiversity protection.

A Confirmatory Factor Analysis (CFA) has been run on the hard and soft behaviour items (Bélanger 2012), confirming the two-factor structure (hard vs. soft behaviours) of the scale (Table 2). The items of the motives for environmental concern scale have been aggregated as suggested by Schultz (2001) in the three factors: biospheric motives, egoistic motives, and altruistic motives. The HaN scale items have been aggregated as suggested by De Groot Drenthen and De Groot (2011) in the four factors: mastery over nature, stewardship of nature, partnership with nature, and participation in nature.

The reliability value of each construct was satisfactory. With reference to two-item measures, Pearson's $r$ was always significant and ranged between 0.27 and 0.58 ; as to multi-item measures, Cronbach's alpha ranged between 0.66 and 0.93 (see online supplemental data for detailed statistics). 
Table 1. EFA: results and factors loadings of B20.

\begin{tabular}{|c|c|c|c|}
\hline Item & $\begin{array}{c}\text { Factor } 1 \\
\text { Positive self } \\
\text { and positive } \\
\text { relations with } \\
\text { others and nature }\end{array}$ & $\begin{array}{c}\text { Factor } 2 \\
\text { Power of self } \\
\text { and negative } \\
\text { emotions towards } \\
\text { the others }\end{array}$ & $\begin{array}{c}\text { Factor } 3 \\
\text { Union and } \\
\text { spirituality }\end{array}$ \\
\hline Curiosity and learning & 0.769 & & \\
\hline Pleasure to be good at & 0.762 & & \\
\hline Pleasure in collaborating & 0.722 & & \\
\hline Care for nature and future generation & 0.696 & & \\
\hline Attachment & 0.681 & & \\
\hline Value in itself & 0.652 & & \\
\hline Social benefits & 0.630 & & \\
\hline Beauty & 0.616 & & \\
\hline Care for family & 0.613 & & \\
\hline Good and worth life & 0.595 & & \\
\hline Duty and responsibility & 0.447 & & \\
\hline Insecurity and anxiety & & 0.810 & \\
\hline Control & & 0.759 & \\
\hline Anger-negative emotions & & 0.719 & \\
\hline Recognition & & 0.667 & \\
\hline Prevent collision & & 0.555 & \\
\hline Religious - spirituality & & & 0.721 \\
\hline Connectedness & & & 0.578 \\
\hline Destiny & & & 0.445 \\
\hline Eigenvalues & 6.24 & 2.15 & 1.65 \\
\hline Explained variance & 31.2 & 10.8 & 8.3 \\
\hline Mean & 5.38 & 3.38 & 4.02 \\
\hline Cronbach's alpha & 0.86 & 0.78 & 0.61 \\
\hline
\end{tabular}

\subsection{Cluster analysis for group identification}

To test the soundness of the a-priori HM-AN vs. NO-AN distinction, a Hierarchical Cluster Analysis (HCA, measure: Squared Euclidean distance; clustering method: Ward's method) has been run. Respondents were grouped on the basis of their scores in pro-environmental behaviours, and then the profile of each group in terms of socialpsychological variables, behaviours and socio-demographic characteristics was tested. Three distinct clusters were extracted from HCA. Comparatively, one cluster, labelled as 'green', scored higher in pro-environmental responses than another cluster, labelled as 'non-green', with the remaining cluster being in the middle.

Based on this outcome, respondents can be grouped and contrasted in three similar ways. Each comparison was largely overlapping with the initial theoretical distinction between HM-AN and NO-AN. The categorization that best fitted the data showed $83.94 \%$ of overlapping with the initial distinction. In order to verify differences of frequencies between HM-AN and NO-AN in the three clusters, a Chi-Square Test was performed. Results showed that HM-AN individuals are significantly overrepresented $\left(X_{(2)}^{2}=28.04, p<0.001\right)$ in the 'green' cluster $(69.15 \%)$ and underrepresented in the 'non-green' cluster (30.88\%). 
Table 2. CFA: results and factors loadings of soft and hard behaviors scale.

\begin{tabular}{lcc}
\hline Item & $\begin{array}{c}\text { Factor 1 } \\
\text { Soft behaviors }\end{array}$ & $\begin{array}{c}\text { Factor 2 } \\
\text { Hard behaviors }\end{array}$ \\
\hline $\begin{array}{l}\text { I sensitized close relatives or colleagues in order that } \\
\text { they change their habits and undertake eco- }\end{array}$ & 0.883 & \\
$\quad$ friendly behaviors & & \\
I sent e-mails about environmental news or & 0.750 & \\
$\quad$ ecological consumptions & 0.725 & 0.854 \\
I financially supported an organization that works for & & \\
$\quad$ the environmental cause & & 0.750 \\
I joined a radical activist group to perform risky or \\
$\quad$ illegal actions in order to help the environmental \\
$\quad$ cause
\end{tabular}

\subsection{HM-AN profiling: comparisons with $\mathrm{NO}-\mathrm{AN}$ and MABP test}

To test the first four hypotheses referring to the social-psychological profiling of HM-AN leaders compared to NO-AN, a series of analyses of variance was performed. All the constructs identified at the: (1) individual, (2) relational, and (3) motivational level of analysis, as well as for (4) concrete action, were considered.

With reference to individual level variables $(\mathrm{H} 1)$, several significant differences emerged on universal values (Table 3). HM-AN people scored higher than NO-AN on unity with nature $\left(F_{(1,179)}=17.53 ; p=0.000\right)$, world of beauty $\left(F_{(1,181)}=11.06 ; p=\right.$ $0.001)$, protecting the environment $\left(F_{(1,180)}=15.26 ; p=0.000\right)$, and variety of life $\left(F_{(1,178)}=3.78 ; p=0.053\right)$, while NO-AN scored higher on enjoying life $\left(F_{(1,177)}=\right.$ $4.87 ; p=0.029)$ and national security $\left(F_{(1,179)}=5.63 ; p=0.019\right)$. Moreover, HM-AN leaders scored higher on ATD $\left(F_{(1,181)}=14.80 ; p=0.000\right)$, perceived behavioural control $\left(F_{(1,181)}=14.09, p=0.000\right)$, awareness of consequences $\left(F_{(1,181)}=6.50 ; p=\right.$ $0.012)$, and personal normative beliefs $\left(F_{(1,181)}=12.20 ; p=0.001\right)$. No significant difference emerged on the other variables.

With reference to the relational level $(\mathrm{H} 2)$, significant differences between the two groups emerged on environmental identity $\left(F_{(1,180)}=17.55 ; p=0.000\right)$, INS $\left(F_{(1,178)}=\right.$ $8.05 ; p=0.005), \operatorname{NHIP}\left(F_{(1,179)}=4.20 ; p=0.042\right), \operatorname{CNS}\left(F_{(1,181)}=16.37 ; p=0.000\right)$, HaN-mastery over nature $\left(F_{(1,179)}=12.46 ; p=0.001\right)$, HaN-stewardship of nature $\left(F_{(1,180)}=4.17 ; p=0.043\right)$, and HaN-participation in nature $\left(F_{(1,179)}=3.91 ; p=0.049\right)$. With the exception of HaN-mastery over nature, HM-AN leaders scored higher than NOAN (Table 4). No significant difference emerged on the other variables.

With reference to motivation (H3), significant differences emerged on Biospheric motives for Environmental concern $\left(F_{(1,181)}=12.03, p=0.001\right)$, Willingness to sacrifice 
Table 3. Individual level variables by group: means and significant differences.

\begin{tabular}{lcrcc}
\hline Variable & Group & $N$ & Mean & St. dev. \\
\hline Unity with nature & HM-AN & 102 & $6.32^{\mathrm{a}}$ & 0.87 \\
& NO-AN & 80 & $5.64^{\mathrm{b}}$ & 1.30 \\
Protecting the environment & HM-AN & 102 & $6.41^{\mathrm{a}}$ & 0.87 \\
& NO-AN & 80 & $5.79^{\mathrm{b}}$ & 1.28 \\
World of beauty & HM-AN & 101 & $5.77^{\mathrm{a}}$ & 1.19 \\
& NO-AN & 80 & $5.14^{\mathrm{b}}$ & 1.37 \\
Exciting Life & HM-AN & 101 & $5.37^{\mathrm{a}}$ & 1.26 \\
& NO-AN & 81 & $5.00^{\mathrm{b}}$ & 1.49 \\
Variety of life & HM-AN & 100 & $5.64^{\mathrm{a}}$ & 1.01 \\
& NO-AN & 80 & $5.30^{\mathrm{b}}$ & 1.33 \\
Enjoying life & HM-AN & 100 & $5.28^{\mathrm{b}}$ & 1.20 \\
& NO-AN & 79 & $5.65^{\mathrm{a}}$ & 0.94 \\
National security & HM-AN & 101 & $4.42^{\mathrm{b}}$ & 1.57 \\
Affinity toward ecological diversity & NO-AN & 80 & $4.99^{\mathrm{a}}$ & 1.65 \\
& HM-AN & 102 & $6.47^{\mathrm{a}}$ & 0.73 \\
Awareness of consequences & NO-AN & 81 & $6.00^{\mathrm{b}}$ & 0.90 \\
& HM-AN & 102 & $6.06^{\mathrm{a}}$ & 0.84 \\
Perceived behavioral control & NO-AN & 81 & $5.69^{\mathrm{b}}$ & 1.09 \\
Personal normative beliefs & HM-AN & 102 & $5.92^{\mathrm{a}}$ & 0.85 \\
& NO-AN & 81 & $5.69^{\mathrm{b}}$ & 1.09 \\
& HM-AN & 102 & $5.61^{\mathrm{a}}$ & 1.13 \\
& NO-AN & 81 & $5.01^{\mathrm{b}}$ & 1.16 \\
\hline
\end{tabular}

Note: $p<0.05$

Table 4. Relational level variables by group: means and significant differences.

\begin{tabular}{lcrcc}
\hline Variable & Group & $N$ & Mean & St. dev. \\
\hline Environmental identity & HM-AN & 102 & $6.33^{\mathrm{a}}$ & 0.83 \\
& NO-AN & 80 & $5.71^{\mathrm{b}}$ & 1.16 \\
INS & HM-AN & 101 & $5.22^{\mathrm{a}}$ & 1.32 \\
& NO-AN & 79 & $4.66^{\mathrm{b}}$ & 1.31 \\
NHIP & HM-AN & 100 & $6.01^{\mathrm{a}}$ & 1.08 \\
& NO-AN & 81 & $5.66^{\mathrm{b}}$ & 1.19 \\
CNS & HM-AN & 102 & $5.44^{\mathrm{a}}$ & 1.21 \\
& NO-AN & 81 & $4.69^{\mathrm{b}}$ & 1.25 \\
HaN-mastery & HM-AN & 101 & $2.90^{\mathrm{b}}$ & 1.06 \\
& NO-AN & 81 & $3.50^{\mathrm{a}}$ & 1.22 \\
HaN-stewardship & HM-AN & 100 & $6.48^{\mathrm{a}}$ & 0.66 \\
\multirow{2}{*}{ HaN-participation } & NO-AN & 80 & $6.24^{\mathrm{b}}$ & 0.93 \\
& HM-AN & 100 & $4.77^{\mathrm{a}}$ & 1.43 \\
& NO-AN & 81 & $4.32^{\mathrm{b}}$ & 1.60 \\
\hline
\end{tabular}

Note: $p<0.05$. Letters ${ }^{\mathrm{a}}$ and ${ }^{\mathrm{b}}$ indicate that means between groups are significantly different. 
Table 5. Motivational level variables by group: means and significant differences.

\begin{tabular}{lcrcc}
\hline Variable & Group & $N$ & Mean & St. dev. \\
\hline Willingness to sacrifice & HM-AN & 102 & $6.03^{\mathrm{a}}$ & 0.69 \\
& NO-AN & 81 & $5.42^{\mathrm{b}}$ & 1.09 \\
B20-Union and spirituality & HM-AN & 102 & $3.89^{\mathrm{a}}$ & 1.20 \\
& NO-AN & 79 & $3.48^{\mathrm{b}}$ & 1.34 \\
Biospheric motives for environmental concern & HM-AN & 102 & $6.32^{\mathrm{a}}$ & 0.87 \\
& NO-AN & 81 & $5.83^{\mathrm{b}}$ & 1.05 \\
\hline
\end{tabular}

Note: $p<0.05$. Letters ${ }^{\mathrm{a}}$ and ${ }^{\mathrm{b}}$ indicate that means between groups are significantly different.

Table 6. Concrete actions level variables by group: means and significant differences.

\begin{tabular}{lcrrr}
\hline Variable & Group & $N$ & Mean & St. dev. \\
\hline Disposition to connect to nature & HM-AN & 102 & $3.56^{\mathrm{a}}$ & 0.90 \\
& NO-AN & 81 & $3.21^{\mathrm{b}}$ & 0.90 \\
Self-education & HM-AN & 102 & $4.67^{\mathrm{a}}$ & 1.13 \\
& NO-AN & 80 & $3.98^{\mathrm{b}}$ & 1.18 \\
Recycling & HM-AN & 102 & $6.61^{\mathrm{b}}$ & 0.74 \\
& NO-AN & 81 & $6.82^{\mathrm{a}}$ & 0.44 \\
Soft behaviours & HM-AN & 102 & $4.05^{\mathrm{a}}$ & 1.31 \\
& NO-AN & 81 & $3.26^{\mathrm{b}}$ & 1.27 \\
Activism & HM-AN & 102 & $5.10^{\mathrm{a}}$ & 0.98 \\
& NO-AN & 80 & $3.96^{\mathrm{b}}$ & 1.32 \\
\hline
\end{tabular}

Note: $p<0.05$. Letters ${ }^{\mathrm{a}}$ and ${ }^{\mathrm{b}}$ indicate that means between groups are significantly different.

$\left(F_{(1,181)}=20.98 ; p=0.000\right)$, B20-Union and spirituality $\left(F_{(1,179)}=1.71 ; \mathrm{p}=0.033\right)$, with HM-AN leaders scoring higher than NO-AM (Table 5). No significant difference emerged on the other variables.

With reference to concrete actions variables (H4), significant differences also emerged (see Table 6). HM-AN leaders scored higher than NO-AN on disposition to connect to nature $\left(F_{(1,181)}=6.29 ; p=0.013\right)$, self-education $\left(F_{(1,181)}=16.08 ; p=\right.$

Table 7. Social-psychological profiling of HM-AN: distinctive features compared to NO-AN.

\begin{tabular}{ll}
\hline Level of analysis & \multicolumn{1}{c}{ Distinctive variables of HM-AN } \\
\hline Individual & $\begin{array}{c}\text { Unity with nature, protecting the environment, world of beauty, variety of life, } \\
\text { enjoying life (lower score), national security (lower score), ATD, awareness } \\
\text { of consequences, perceived behavioural control, personal normative beliefs } \\
\text { Environmental identity, INS, NHIP, CNS, HaN-mastery (lower score), } \\
\text { HaN-stewardship, HaN-participation }\end{array}$ \\
Relational & $\begin{array}{l}\text { Willingness to sacrifice, B20-Union and spirituality, biospheric motives for } \\
\text { environmental concern } \\
\text { Motivation }\end{array}$ \\
Concrete actions & $\begin{array}{l}\text { Disposition to connect to nature, self-education, recycling (lower score), soft } \\
\text { behaviours, activism }\end{array}$ \\
\hline
\end{tabular}


Table 8. HMRA: predictors of activism.

\begin{tabular}{|c|c|c|c|c|c|}
\hline \multirow[b]{2}{*}{ Predictors } & \multicolumn{3}{|c|}{$\beta$ coefficients } & \multirow[b]{2}{*}{ Adjusted $R^{2}$} & \multirow[b]{2}{*}{$R^{2}$ change } \\
\hline & Step 1 & Step 2 & Step 3 & & \\
\hline Step 1 & & & & $0.44^{* * *}$ & \\
\hline Unity with nature & $0.28^{* * *}$ & $0.23^{*}$ & 0.13 & & \\
\hline World of beauty & 0.13 & 0.03 & 0.01 & & \\
\hline Protecting the environment & -0.14 & -0.07 & -0.04 & & \\
\hline Perceived behavioural control & $0.16^{*}$ & 0.07 & 0.04 & & \\
\hline Awareness of consequences & $0.30^{* * *}$ & $0.18^{*}$ & $0.14^{*}$ & & \\
\hline Personal normative beliefs & $0.25^{* *}$ & 0.10 & 0.07 & & \\
\hline Step 2 & & & & $0.53^{* * *}$ & $0.09^{* * *}$ \\
\hline Environmental identity & & $0.16^{*}$ & 0.09 & & \\
\hline CNS & & -0.04 & -0.06 & & \\
\hline NHIP & & $0.14^{*}$ & 0.13 & & \\
\hline $\mathrm{HaN}$-participation & & $0.24^{* *}$ & $0.26^{* *}$ & & \\
\hline Step 3 & & & & $0.62^{* * *}$ & $0.09^{* * *}$ \\
\hline Motivation & & & $0.36^{* * *}$ & & \\
\hline
\end{tabular}

${ }^{* * *} p<0.001 ;{ }^{* *} p<0.01 ;{ }^{*} p<0.05$.

$0.000)$, soft behaviours $\left(F_{(1,181)}=16.45, p=0.000\right)$, and activism $\left(F_{(1,181)}=44.96 ; p=\right.$ $0.000)$, while NO-AN scored higher on GEB measures of recycling behaviours $\left(F_{(1,181)}\right.$ $=4.64 ; p=0.032$ ). No significant difference emerged on the other variables.

Table 7 gives a summary of distinctive social-psychological features of HM-AN compared to NO-AN.

Finally, a Hierarchical Multiple Regression Analysis (HMRA) was performed to assess the integrative MABP (H5; Figure 1). Preliminarily, Cronbach's alpha for the variables referring to motivation was checked $(\alpha=0.78)$ and an aggregated measure of Motivation was computed. A correlation matrix between all the individual and relational variables considered in the study, Motivation, and Activism, was then calculated (see online supplemental data for detailed statistics). Predictors showing a significant correlation with the criterion $(p<0.01)$ were retained for subsequent analyses, namely unity with nature, world of beauty, protecting the environment, perceived behavioural control, awareness of consequences, personal normative believes, environmental identity, CNS, NHIP, HaN-participation, and motivation. At steps 1, 2, and 3 of the HMRA individual variables, relational variables and motivation, respectively, were entered as predictors of activism (Table 8). At step 1, the model was significant and the individual variables unity with nature, perceived behavioural control, awareness of consequences, and personal normative beliefs emerged as significant predictors of activism. At step 2, the model significantly increased the amount of explained variance, being environmental identity, NHIP, and HaNparticipation significant predictors of activism. Perceived behavioural control and perceived normative beliefs were no more significant. At step 3, the model still increased the amount of explained variance, and motivation also emerged as a significant predictor of activism. Only awareness of consequences and $\mathrm{HaN}$ participation still showed a significant association with activism. Mediation analyses 
performed through the Sobel test showed that motivation fully mediates the effect of unity with nature $(z$-value $=4.75, p<0.001)$, environmental identity $(z$-value $=4.81, p$ $<0.001)$, and NHIP $(z$-value $=4.01, p<0.001)$ on motivation. The effect of awareness of consequences $(z$-value $=4.19, p<0.001)$ on activism was partially mediated by motivation. The effect of HaN-participation on activism was direct.

\section{Discussion}

This study helps shed light on key social-psychological determinants of activism in nature and biodiversity protection. To this aim, outstanding EU leaders committed to biodiversity protection (HM-AN) have been compared to both leaders in nonenvironmental action and non-leaders in nature-related activities (NO-AM). In this comparison, a variety of individual and relational variables has been considered, being previously identified in the literature as relevant determinants of pro-environmental behaviours and activism. This was made in order to sketch out a picture as comprehensive as possible of leaders in nature and biodiversity protection within the EU, across different activity sectors.

After checking the psychometric properties of the adopted tools, a cluster analysis confirmed the soundness of the HM-AN vs. NO-AN distinction in terms of behaviours in favour of nature and biodiversity. The analysis of the individual-psychological level confirmed the importance of Schwartz's (1992) universal values of self-transcendence (e.g. universalism) and self-enhancement (e.g. power) as relevant determinants of such a target action, similarly to other pro-environmental behaviours (Karp 1996; Steg and Vlek 2009). More specifically, HM-AN leaders attribute stronger importance to unity with nature, protection of the environment, beauty of the world, variety of life, and less importance to national security and enjoying life than NO-AN. These guiding principles of their life suggested the idea of being part of the natural world, which is an interconnected and amazing variety of plants and animals. The idea of power and domination, as frequently expressed in civil society, is far from being a relevant aspect of their experience. Other significant differences emerged with reference to TPB and VBN variables. HM-AN leaders showed a more positive attitude towards ecological diversity, a stronger perceived behavioural control, a deeper awareness of the negative consequences of not acting for nature and biodiversity, and higher feelings of moral normative obligation to take initiatives for the sake of biodiversity, thus confirming previous findings on other pro-environmental behaviours (Fielding, McDonald, and Louis 2008; Kollmuss and Agyeman 2002). Conversely, they did not show higher scores of self-efficacy than NO-AN. This confirmed the fundamental role of self-efficacy in whatever collective action, independently of the environmental vs. social issue at stake (van Zomeren, Postmes, and Spears 2008).

As to the relational level of analysis, no difference between the two groups emerged for place identity. This interesting outcome may be presumably related to the more local $v s$. global goal of the actors' action. People of both groups showed a strong commitment to the community to which they belong, which defines a relevant part of their identity, and thus drives their initiatives (Simon et al. 1998; van Zomeren, Postmes, and Spears 2008). One group emphasizes the social side of the social-ecological milieu, while the other the ecological one. These aspects do not often reconcile (Tidball and Stedman 2013). But social activists are more locally-oriented, and often take initiatives in those places where they want a change to occur, even though they are interested in changing society as well (Staggenborg 1998; Starr 2010). Conversely, the identification process 
with the Earth and the natural world as a whole clearly distinguishes HM-AN leaders, and this seems to shape their own self-image (Clayton 2003; Schultz 2001). This affects the worldviews of HM-AN leaders, who scored higher on NHIP, CNS, and HaN scales, thus showing a stronger perception of the interdependence between humans and nature (Davis, Green, and Reed 2009). The two groups seem to differ in how they fit their intentions and natural world together. NO-AH seems to hold what Searle (2010) calls the world-to-mind direction of fit. The outside world has to change to fit better with their intentions. Conversely, HM-AN leaders have the mind-to-world direction, calling for a change in people's desires and intentions to fit them better with the natural conditions.

Interestingly, one aspect of the relational level, namely the organizational aspect, does not distinguish the two groups. Scores of collective efficacy, organizational empowerment, and transformational leadership were very high for both. Well-organized teamwork and a rich surrounding network emerged as key determinants of performance and collective actions for whatever change in societies (Balkundi and Harrison 2006; Guzzo and Dickson 1996).

High levels of motivation were consistently identified as a distinctive feature of activists (Den Hond and De Bakker 2007; James, Bixler, and Vadala 2010). HM-AN leaders showed a very peculiar pattern of motivation. Both groups have similar levels of egoistic motivations behind their action, referring to the negative consequences of social or environmental problems on their own life, and altruistic motivations, referring to the impact on others (De Dominicis, Schultz, and Bonaiuto 2017); but only HM-AN leaders showed exceptional levels of motivations concerning the well-being of plants and animals (Schultz 2001; van den Born et al. 2017). In addition, they showed a stronger willingness to sacrifice some personal benefits and comfort in everyday life, including a change in their own lifestyle, in order to support nature and biodiversity. This corroborates research evidence showing that personal and ecological well-being are highly compatible once people have internalized adequate psychological dispositions (Brown and Kasser 2005). Finally, HM-AN leaders showed a strong intrinsic motivation in nature and biodiversity protection, which is embedded in the feeling of a spiritual connection with the natural world. This result is consistent with previous findings (Vining 2003).

With reference to pro-environmental behaviours, the picture is also interesting. HMAN and NO-AN did not differ in everyday pro-environmental behaviours (e.g. transportation choices). In accordance with Green-Demers, Pelletier, and Menard (1997), these can be examples of the easy/average difficulty levels of pro-environmental behaviour. However, HM-AN leaders clearly moved a step forward - without engaging in extreme illegal actions for the environment - with reference to higher difficulty levels, and even uncommon behaviours, like talking to plants, and helping animals cross the street. That is compatible with a spiritual feeling of connection with the natural world, as discussed above, and with the aesthetic appreciation of nature and felt obligations towards nature (Rolston 2002). In addition, HM-AN leaders were more interested in participation in meetings about environmental issues, thus showing curiosity and willingness of engagement in a continuous learning process, which are more demanding behaviours. This is consistent with the idea that environmental issues are to be shared with others, in order to make a change (Séguin, Pelletier, and Hunsley 1998; Stern et al. 1999).

Finally, to give a comprehensive picture of HM-AN leaders, some empirical support to our MABP was found. Committed action for nature and biodiversity protection emerged as an integration of individual and relational variables influencing motivation and this, in turn, activism. Unity with nature and awareness of consequences were 
identified as the key factors at the individual level; environmental identity, NHIP, and HaN-participation emerged as the main determinants at the relational level. Their effect on activism was largely mediated by motivation, with the exception of HaN-participation and awareness of consequences, which showed a significant direct effect. Overall, these findings further corroborate the feeling of human-nature interdependence shared among HM-AN leaders.

Some limitations of the study can be acknowledged. First of all, the wide socialpsychological focus adopted forced the frequent use of two-item scales in the questionnaire, in order to avoid cognitive fatigue on the respondents. In principle, that may raise validity issues. However, the reliability indexes of the measures were generally satisfactory. In addition, some of the considered constructs probably partially overlap, even though correlations were never problematic. Future research should focus on a narrower set of relevant variables, and use complete scales. Moreover, the relationships among all these variables should be better understood, through a more comprehensive testing of mediation and moderation links. Finally, another key aspect is to understand which specific environmental ordinary or extraordinary experiences can promote the development of such a social-psychological profile (Amel et al. 2017; van den Born et al. 2017). The 'snapshot' discussed here needs to be completed by the 'movie' behind it.

This study offers suggestions for applications in terms of training, education, and communication guidelines. Programs of environmental education should mainly promote those factors that best represent the HM-AN profile. Deeper biospheric values, particularly among the youngest generations, would probably foster identity processes anchored on human-nature interdependence, and these increase the likelihood of congruent beliefs, including the awareness of consequences for biodiversity loss.

Finally, the communication of proper normative messages by outstanding individuals for biodiversity preservation should not be neglected (Amel et al. 2017). This could trigger a virtuous circle where the perception of others doing something in such a direction can provide a cue for those not acting yet. The identification of the socialpsychological profile of HM-AN also allows us to view critically the selection of socalled 'forerunners' to foster pro-environmental transition processes (Loorbach and Rotmans 2010), or stakeholders within science-society partnerships for collaborative biodiversity planning (Brand et al. 2013).

All these applications can be interdependent in promoting more and more people sharing some key social-psychological features that blended together seem to be associated with committed action for nature and biodiversity across time and contexts.

\section{Disclosure statement}

No potential conflict of interest was reported by the authors.

\section{Funding}

The present research had been supported by the BIOMOT EC Seventh Framework Programme "MOTivational strength of ecosystem services and alternative ways to express the value of BIOdiversity" [BIOMOT; call ENV.2011.2.1.4-3, grant number FP7 282625].

\section{Supplemental data}

Supplemental data for this article can be accessed 10.1080/09640568.2017.1421526 


\section{ORCID}

Mirilia Bonnes (D) http://orcid.org/0000-0002-7323-7063

Stefano De Dominicis (D) http://orcid.org/0000-0002-8165-8028

Marino Bonaiuto (iD http://orcid.org/0000-0002-4543-5329

\section{References}

Admiraal, J., R. J. G. van den Born, A. Beringer, F. Bonaiuto, L. Cicero, J. Hiedanpää, P. Knights, et al. 2017. "Motivations for Committed Nature Conservation Action in Europe." Environmental Conservation 44 (2): 148-159.

Ajzen, I. 1991. "The Theory of Planned Behaviour." Organizational Behaviour and Human Decision Processes 50 (2): 179-211.

Amel, E., C. Manning, B. Scott, and S. Koger. 2017. "Beyond the Roots of Human Inaction: Fostering Collective Efforts Toward Ecosystem Conservation.” Science (New York, N.Y.) 365 (6335): 275-279.

Armitage, C. J., and M. Conner. 2001. "Efficacy of the Theory of Planned Behaviour: A MetaAnalytic Review." British Journal of Social Psychology 40 (4): 471-499.

Balkundi, P., and D. A. Harrison. 2006. "Ties, Leaders, and Time in Teams: Strong Inference About Network Structure's Effects on Team Viability and Performance." Academy of Management Journal 49 (1): 49-68.

Balmford, A., A. Bruner, P. Cooper, R. Costanza, S. Farber, R. E. Green, M. Jenkins, et al. 2002. "Economic Reasons for Conserving Wild Nature." Nature 297 (5583): 950-953.

Bandura, A. 1982. "Self-Efficacy Mechanism in Human Agency." American Psychologist 37 (2): $122-147$.

Barr, S. 2007. "Factors Influencing Environmental Attitudes and Behaviors a UK Case Study of Household Waste Management." Environment and Behavior 39 (4): 435-473.

Bass, B. M., and R. E. Riggio. 2006. Transformational Leadership. Mahwah, NJ: Lawrence Erlbaum Associates.

Bechtel, R. B., V. Corral-Verdugo, and J. de Queiroz Pinheiro. 1999. "Environmental Belief Systems: United States, Brazil, and Mexico." Journal of Cross-Cultural Psychology 30 (1): 122-128.

Bechtel, R. B., V. Corral-Verdugo, M. Asai, and A. Riesle. 2006. "A Cross-Cultural Study of Environmental Belief Structures in USA, Japan, Mexico, and Peru." International Journal of Psychology 41 (2): 145-151.

Bélanger, J. J. 2012. “The Psychology of Martyrdom.” Manuscript under preparation. Unpublished $\mathrm{PhD}$ diss, University of Maryland.

Bonaiuto, M., E. Bilotta, M. Bonnes, M. Ceccarelli, H. Martorella, and G. Carrus. 2008. "Local Identity and the Role of Individual Differences in the Use of Natural Resources: The Case of Water Consumption." Journal of Applied Social Psychology 38: 947-967.

Bonaiuto, M., G. M. Breakwell, and I. Cano. 1996. "Identity Processes and Environmental Threat: The Effects of Nationalism and Local Identity upon Perception of Beach Pollution." Journal of Community and Applied Social Psychology 6: 157-175.

Bonaiuto, M., G. Carrus, H. Martorella, and M. Bonnes. 2002. "Local Identity Processes and Environmental Attitudes in Land Use Changes: The Case of Natural Protected Areas." Journal of Economic Psychology 23: 631-653.

Bonnes, M., and M. Bonaiuto. 2002. "Environmental Psychology: From Spatial-Physical Environment to Sustainable Development." In Handbook of Environmental Psychology, edited by R. Bechtel and A. Churchman, 28-54. New York: Wiley.

Bonnes, M., M. Bonaiuto, A. M. Nenci, and G. Carrus. 2011. "Environmental and Human Diversities in the City: An Introduction." In Urban Diversities: Environmental and Social Issues, edited by M. Bonaiuto, M. Bonnes, A. M. Nenci, and G. Carrus, 3-15. Gottingen: Hoegrefe.

Botetzagias, I., and W. van Schuur. 2012. "Active Greens: An Analysis of the Determinants of Green Party Members' Activism in Environmental Movements." Environment and Behavior 44 (4): 509-544.

Brand, F. S., R. Seidl, Q. B. Le, J. M. Brändle, and R. W. Scholz. 2013. "Constructing Consistent Multiscale Scenarios by Transdisciplinary Processes: The Case of Mountain Regions Facing Global Change." Ecology and Society 18 (2): 43. doi:10.5751/ES-04972-180243 
Brechin, S. R., and W. Kempton. 1994. "Global Environmentalism: A Challenge to the Postmaterialism Thesis?" Social Science Quarterly 75 (2): 245-269.

Brown, R. 2000. "Social Identity Theory: Past Achievements, Current Problems and Future Challenges." European Journal of Social Psychology 30 (6): 745-778.

Brown, K. W., and T. Kasser. 2005. "Are Psychological and Ecological Well-Being Compatible? The Role of Values, Mindfulness, and Lifestyle." Social Indicators Research 74 (2): 349-368.

Casey, P. J., and K. Scott. 2006. "Environmental Concern and Behaviour in an Australian Sample Within an Ecocentric-Anthropocentric Framework." Australian Journal of Psychology 58 (2): $57-67$.

Ceballos, G., P. R. Ehrlich, A. D. Barnosky, A. García, R. M. Pringle, and T. M. Palmer. 2015. "Accelerated Modern Human-Induced Species Losses: Entering the Sixth Mass Extinction." Science Advances 1 (5): e1400253.

Chen, G., S. M. Gully, and D. Eden. 2001. "Validation of a New General Self-Efficacy Scale." Organizational Research Methods 4 (1): 62-83.

Clayton, S. 2003. "Environmental Identity: A Conceptual and An Operational Definition." In Identity and the Natural Environment. edited by S. Clayton and S. Opotow, 45-65. Cambridge, MA: MIT PRESS.

Clayton, S., P. Devine-Wright, J. Swim, M. Bonnes, L. Steg, L. Whitmarsh, and A. Carrico. 2015. "Expanding the Role for Psychology in Addressing Environmental Challenges." American Psychologist 70: 1-16.

Corral-Verdugo, V., G. Carrus, M. Bonnes, G. Moser, and J. B. Sinha. 2008. "Environmental Beliefs and Endorsement of Sustainable Development Principles in Water Conservation Toward A New Human Interdependence Paradigm Scale." Environment and Behavior 40 (5): $703-725$.

Corral-Verdugo, V., M. Bonnes, C. Tapia-Fonllem, B. Fraijo-Sing, M. Frías-Armenta, and G. Carrus. 2009. "Correlates of Pro-Sustainability Orientation: The Affinity Towards Diversity." Journal of Environmental Psychology 29 (1): 34-43.

Costanza, R., R. d'Arge, R. De Groot, S. Farber, M. Grasso, B. Hannon, K. Limburg, et al. 1997. "The Value of the World's Ecosystem Services and Natural Capital." Nature 387 (6630): 253260.

Davis, J. L., J. D. Green, and A. Reed. 2009. "Interdependence with the Environment: Commitment, Interconnectedness, and Environmental Behavior." Journal of Environmental Psychology 29 (2): $173-180$.

Dedeurwaerdere, T., A. Polard, and P. Melindi-Ghidi. 2015. "The Role of Network Bridging Organisations in Compensation Payments for Agri-Environmental Services under the EU Common Agricultural Policy." Ecological Economics 119: 24-38.

Dedeurwaerdere, T., Admiraal, J., Beringer, A., Bonaiuto, F., Cicero, L., Fernandez-Wulff, P., Janneke, et al. 2016. "Combining Internal and External Motivations in Multi-Actor Governance Arrangements for Biodiversity and Ecosystem Services." Environmental Science and Policy 58: 1-10.

De Dominicis, S., W. Schultz, and M. Bonaiuto. 2017. "Protecting the Environment for Selfish Reasons: Altruism is not the Only Pathway to Sustainability." Frontiers in Psychology 8: 1065. doi:10.3389/fpsyg.2017.01065

De Groot, M., M. Drenthen, and W. T. De Groot. 2011. "Public Visions of the Human/Nature Relationship and their Implications for Environmental Ethics." Environmental Ethics 33 (1): 25-44.

De Groot, W. T., M. Bonaiuto, T. Dedeurwaerdere, and L. Knippenberg. 2015. A Theory of Committed Action for Nature. Nijmegen: The BIOMOT Project, ISIS, Faculty of Science, Radboud University Nijmegen. http://www.biomot.eu/outcomes.php.

Den Hond, F., and F. G. De Bakker. 2007. "Ideologically Motivated Activism: How Activist Groups Influence Corporate Social Change Activities.” Academy of Management Review 32 (3): 901924.

Dietz, T., P. C. Stern, and G. A. Guagnano. 1998. "Social Structural and Social Psychological Bases of Environmental Concern." Environment and Behavior 30 (4): 450-471.

Dono, J., J. Webb, and B. Richardson. 2010. "The Relationship Between Environmental Activism, Pro-Environmental Behaviour and Social Identity." Journal of Environmental Psychology 30 (2): $178-186$. 
Dudgeon, D., A. H. Arthington, M. O. Gessner, Z-I Kawabata, D. J. Knowler, C. Leveque, R. J. Naiman, et al. 2006. "Freshwater Biodiversity: Importance, Threats, Status and Conservation Challenges." Biological Reviews 81 (2): 163-182.

Dunlap, R. E., and K. D. Van Liere. 1978. "The 'New Environmental Paradigm'.” The Journal of Environmental Education 9 (4): 10-19.

Dutcher, D. D., J. C. Finley, A. E. Luloff, and J. B. Johnson. 2007. "Connectivity with Nature as a Measure of Environmental Values." Environment and Behavior 39 (4): 474-493.

Edwards, T. C., and S. Oskamp. 1992. "Components of Antinuclear War Activism." Basic and Applied Social Psychology 13 (2): 217-230.

Fielding, K. S., R. McDonald, and W. R. Louis. 2008. "Theory of Planned Behaviour, Identity and Intentions to Engage in Environmental Activism." Journal of Environmental Psychology 28 (4): 318-326.

Fishbein, M., and I. Ajzen. 1975. Belief, Attitude, Intention, and Behaviour: An Introduction to Theory and Research. Reading, MA: Addison-Wesley.

Foley, J. A., N. Ramankutty, K.A. Brauman, E. S. Cassidy, J. S. Gerber, M. Johnston, and N. D. Mueller. 2011. "Solutions for a Cultivated Planet." Nature 478 (7369): 337-342.

Fornara, F., G. Carrus, P. Passafaro, and M. Bonnes. 2011. "Distinguishing the Sources of Normative Influence on Pro-Environmental Behaviors: The Role of Local Norms in Household Waste Recycling." Group Processes and Intergroup Relations 14 (5): 623-635.

Gorenflo, L. J., S. Romaine, R. A. Mittermeier, and K. Walker-Painemilla. 2012. "Co-Occurrence of Linguistic and Biological Diversity in Biodiversity Hotspots and High Biodiversity Wilderness Areas." Proceedings of the National Academy of Sciences 109 (21): 8032-8037.

Gosling, E., and K. J. Williams. 2010. "Connectedness to Nature, Place Attachment and Conservation Behaviour: Testing Connectedness Theory Among Farmers." Journal of Environmental Psychology 30 (3): 298-304.

Green-Demers, I., L. G. Pelletier, and S. Menard. 1997. "The Impact of Behavioural Difficulty on the Saliency of the Association between Self-Determined Motivation and Environmental Behaviours." Canadian Journal of Behavioural Science 29 (3): 157-166.

Guzzo, R. A., and M. W. Dickson. 1996. "Teams in Organizations: Recent Research on Performance and Effectiveness." Annual Review of Psychology 47 (1): 307-338.

Halpern, B. S., S. Walbridge, K. A. Selkoe, C. V. Kappel, F. Micheli, C. D’Agrosa, and J. F. Bruno. 2008. "A Global Map of Human Impact on Marine Ecosystems." Science (New York, N.Y.) 319 (5865): 948-952.

Hewstone, M., M. Rubin, and H. Willis. 2002. “Intergroup Bias.” Annual Review of Psychology 53: 575-604.

Homburg, A., and A. Stolberg. 2006. "Explaining Pro-Environmental Behavior with A Cognitive Theory of Stress." Journal of Environmental Psychology 26 (1): 1-14.

Ives, C.D. 2016. "Connections Between People and Nature: A Multidisciplinary Review of the Empirical Literature." Paper presented at the 24th Conference of the International Association for People-Environment Studies (IAPS), Lund, June 27-July 1.

James, J. J., R. D. Bixler, and C. E. Vadala. 2010. "From Play in Nature, to Recreation then Vocation: A Developmental Model for Natural History-Oriented Environmental Professionals." Children Youth and Environments 20 (1): 231-256.

Kaiser, F. G. 1998. "A General Measure of Ecological Behavior." Journal of Applied Social Psychology 28 (5): 395-422.

Karp, D. G. 1996. "Values and their Effect on Pro-Environmental Behavior." Environment and Behavior 28 (1): 111-133.

Klöckner, C. A. 2013. "A Comprehensive Model of the Psychology of Environmental Behaviour: A Meta-analysis." Global Environmental Change 23 (5): 1028-1038.

Kollmuss, A., and J. Agyeman. 2002. "Mind the Gap: Why do People Act Environmentally and What are the Barriers to Pro-Environmental Behavior?" Environmental Education Research 8 (3): 239-260.

Kruglanski, A. W., J. J. Bélanger, M. Gelfand, R. Gunaratna, M. Hettiarachchi, F. Reinares, E. Orehek, J. Sasota, and K. Sharvit. 2013. "Terrorism-A (Self) Love Story: Redirecting the Significance Quest Can End Violence." American Psychologist 68 (7): 559-575.

Kruglanski, A. W., and E. Orehek. 2011. "The Role of the Quest for Personal Significance in Motivating Terrorism." In The Psychology of Social Conflict and Aggression, edited by J. P. Forgas, A. W. Kruglanski, and K. D. Williams, 153-164. New York, NY: Psychology Press. 
Loorbach, D., and J. Rotmans. 2010. "The Practice of Transition Management: Examples and Lessons from Four Distinct Cases." Futures 42 (3): 237-246.

Maxwell, S. L., R. A. Fuller, T. M. Brooks, and J. E. M. Watson. 2016. "Biodiversity: The Ravages of Guns, Nets and Bulldozers." Nature 536 (7615): 143-145.

Mayer, F. S., and C. M. Frantz. 2004. "The Connectedness to Nature Scale: A Measure of Individuals' Feeling in Community with Nature." Journal of Environmental Psychology 24 (4): 503-515.

McFarlane, B. L., and P. C. Boxall. 2003. "The Role of Social Psychological and Social Structural Variables in Environmental Activism: An Example of the Forest Sector." Journal of Environmental Psychology 23 (1): 79-87.

McFarlane, B. L., and L. M. Hunt. 2006. "Environmental Activism in the Forest Sector: Social Psychological, Social-Cultural, and Contextual Effects." Environment and Behavior 38 (2): 266-285.

Millennium Ecosystem Assessment. 2005. Ecosystems and Human Well-Being: Synthesis. Washington, DC: Island Press.

Pillai, R., and E. A. Williams. 2004. "Transformational Leadership, Self-Efficacy, Group Cohesiveness, Commitment, and Performance." Journal of Organizational Change Management 17 (2): 144-159.

Rolston, H., III. 2002. "From Beauty to Duty: Aesthetics of Nature and Environmental Ethics." In Environment and the Arts: Perspectives on Environmental Aesthetics, edited by A. Berleant, 127-142. Aldershot and Burlington: Ashgate.

Rothschild, Z. K., A. Abdollahi, and T. Pyszczynski. 2009. "Does Peace Have A Prayer? The Effect of Mortality Salience, Compassionate Values, and Religious Fundamentalism on Hostility Toward Out-Groups." Journal of Experimental Social Psychology 45 (4): 816-827.

Ryan, R. M., and E. L. Deci. 2000. "Intrinsic and Extrinsic Motivations: Classic Definitions and New Directions." Contemporary Educational Psychology 25 (1): 54-67.

Scannell, L., and R. Gifford. 2010. "The Relations Between Natural and Civic Place Attachment and Pro-Environmental Behavior." Journal of Environmental Psychology 30 (4): 503-515.

Schultz, P. W. 2001. "The Structure of Environmental Concern: Concern for Self, Other People, and the Biosphere." Journal of Environmental Psychology 21 (4): 327-339.

Schultz, P. W., V. V. Gouveia, L. D. Cameron, G. Tankha, P. Schmuck, and M. Franěk. 2005. "Values and their Relationship to Environmental Concern and Conservation Behavior." Journal of Cross-Cultural Psychology 36 (4): 457-475.

Schwartz, S. H. 1992. "Universals in the Content and Structure of Values: Theoretical Advances and Empirical Tests in 20 Countries." Advances in Experimental Social Psychology 25 (1): $1-65$.

Searle, J. 2010. Making the Social World. Oxford: Oxford University Press.

Séguin, C., L. G. Pelletier, and J. Hunsley. 1998. "Toward a Model of Environmental Activism." Environment and Behavior 30 (5): 628-652.

Simon, B., M. Loewy, S. Stürmer, U. Weber, P. Freytag, C. Habig, C. Kampmeier, and P. Spahlinger. 1998. "Collective Identification and Social Movement Participation." Journal of Personality and Social Psychology 74 (3): 646-658.

Spreitzer, G. M. 1996. "Social Structural Characteristics of Psychological Empowerment." Academy of Management Journal 39 (2): 483-504.

Staggenborg, S. 1998. "Social Movement Communities and Cycles of Protest: The Emergence and Maintenance of a Local Women's Movement." Social Problems 45 (2): 180-204.

Starr, A. 2010. "Local Food: A Social Movement?." Cultural Studies - Critical Methodologies 10 (6): 479-490.

Steg, L., and C. Vlek. 2009. "Encouraging Pro-Environmental Behaviour: An Integrative Review and Research Agenda." Journal of Environmental Psychology 29 (3): 309-317.

Stern, P. C., T. Dietz, T. D. Abel, G. A. Guagnano, and L. Kalof. 1999. "A Value-Belief-Norm Theory of Support for Social Movements: The Case of Environmentalism." Human Ecology Review 6 (2): 81-97.

Stern, P. C., and S. Oskamp. 1987. "Managing Scarce Environmental Resources.” In Handbook of Environmental Psychology, edited by D. Stokols and I. Altman, 1043-1088. New York, NY: Wiley.

Tidball, K., and R. Stedman. 2013. "Positive Dependency and Virtuous Cycles: From Resource Dependence to Resilience in Urban Social-Ecological Systems." Ecological Economics 86: 292-299. 
Twigger-Ross, C., M. Bonaiuto, and G. M. Breakwell. 2003. "Identity Theories and Environmental Psychology." In Psychological Theories for Environmental Issues, edited by M. Bonnes, T. Lee, and M. Bonaiuto, 203-233. Aldershot: Ashgate.

van den Born, R. J., B. Arts, J. Admiraal, A. Beringer, P. Knights, E. Molinario, K. Polajnar Horvat, et al. 2017. "The Missing Pillar: Eudemonic Values in the Justification of Nature Conservation." Journal of Environmental Planning and Management. doi:10.1080/ 09640568.2017.134261

van Zomeren, M., T. Postmes, and R. Spears. 2008. "Toward an Integrative Social Identity Model of Collective Action: A Quantitative Research Synthesis of Three Socio-Psychological Perspectives." Psychological Bulletin 134 (4): 504-535.

Vaske, J. J., and M. P. Donnelly. 1999. "A Value-Attitude-Behavior Model Predicting Wildland Preservation Voting Intentions." Society and Natural Resources 12 (6): 523-537.

Vaske, J. J., and K. C. Kobrin. 2001. "Place Attachment and Environmentally Responsible Behavior." The Journal of Environmental Education 32 (4): 16-21.

Vining, J. 2003. "The Connection to Other Animals and Caring for Nature." Human Ecology Review 10 (2): 87-99.

Walumbwa, F. O., P. Wang, J. J. Lawler, and K. Shi. 2004. "The Role of Collective Efficacy in the Relations Between Transformational Leadership and Work Outcomes." Journal of Occupational and Organizational Psychology 77 (4): 515-530. 